\title{
Incentive Regulation, Investments and Technological Change
}

\author{
Ingo Vogelsang
}

CESIFO WORKING PAPER NO. 2964

CATEGORY 11: INDUSTRIAL ORGANISATION

FEBRUARY 2010

\footnotetext{
An electronic version of the paper may be downloaded

- from the SSRN website: Www.SSRN.com

- from the RePEc website: Www.RePEc.org

- from the CESifo website: www.CESifo-group.org/wp
} 


\title{
Incentive Regulation, Investments and Technological Change
}

\begin{abstract}
Based on an idiosyncratic reading of the literature I propose intermediate (rather than tight or soft) regulation for balancing investment incentives with allocative efficiency and competition objectives. Intermediate regulation is compatible with incentive regulation and helps lengthening the regulatory commitment period necessary for incentives. However, such commitment for the whole time horizon of infrastructure or innovation investments is impossible. The compatibility of incentive regulation and efficient investment is thus in doubt. Incentive regulation for regular infrastructure investments therefore needs periodic updating based on rate-of-return regulation criteria. Innovative infrastructure investments may warrant regulatory holidays, which should be conditioned on strict criteria.
\end{abstract}

JEL-Code: L50, L90.

\author{
Ingo Vogelsang \\ Department of Economics \\ Boston University \\ 270 Bay State Road \\ USA - Boston, MA 02215 \\ vogelsan@bu.edu
}

Ifo/CESifo \& OECD Conference on Regulation: Political Economy, Measurement and Effects on Performance

Munich, January 29-30, 2010 


\section{Incentive regulation, investments and technological change Ingo Vogelsang ${ }^{1}$, Boston University and CESifo}

\section{Basic Considerations about Regulation and Investment}

The relationship between regulation and investment appears to be an evergreen problem. In fact, regulation in the U.S. started with the investment issue: Franchise contracts for new infrastructure evolved into regulation. Doubts about investment incentives were swept away by the "Hope" decision (U.S. Supreme Court, 1944), which provided for a stable legal foundation of rate-of-return regulation. When I started working on regulation in the 1970s the main problem tackled by economists was that of regulatory incentives for excessive investment under rate-of-return regulation (AverchJohnson effect). In the 1980s and 90s rate-of-return regulation was replaced by incentive regulation with an emphasis on cost reduction and efficient pricing. Has investment been neglected? What about the over-investment in Telecommunications before 2000/2001? Today regulated incumbents complain that regulation stifles their investment incentives. Their lobbying resulted, for example, in a heavily contested German telecommunications $\mathrm{law}^{2}$ that provides a regulatory holiday for innovative investment as does current practice of the U.S. Federal Communications Commission. Such legal and regulatory measures derive their justification from the presumption that the additional benefits from (innovation and) investment are going to be high relative to benefits foregone from shortterm cost reductions and/or price reductions.

Network industries have specific characteristics posing nontrivial investment issues. They generally exhibit economies of scale persisting over a wide range of output and leading to lumpiness of investments. This lumpiness refers to the size of capacity increments, which can be associated with capacity shortages, excess capacity and (wasteful) duplicate investments. Furthermore, lumpiness refers to long lead times and durability of the investments. A common feature of network investments is sunkness, which implies risks associated with real options. Both the option to wait and thereby learn about the future and the option to have capacity available when it is needed can be

\footnotetext{
${ }^{1}$ The author would like to thank John Kwoka for insightful comments.

${ }^{2} \S$ 9a TKG, effective February 24, 2007.
} 
valuable and thereby influence investment risk. In addition, competitive risks, for example from duplicative investment, can play a major role in investment decisions. Examples of industries with (currently) weak competitive risks include electricity transmission and distribution networks, while strong competitive risks characterize broadband telecommunications access and backhaul and next generation networks (NGN). The fibre networks built in the late 1990s show that the competitive race to be first can lead to overcapacity.

The incentive-regulation movement was a reaction to the rate-of-return regulation tradition (Vogelsang, 2002). In contrast to the emphasis of rate-of-return regulation on potentially excessive investment and its lack of emphasis on productive efficiency and low consumer prices incentive regulation put the emphasis on (short-term) productive efficiency and low consumer prices. This neglected the tradeoff that investment benefits are potentially high relative to benefits from efficient pricing. It does not, however, necessarily mean that incentive regulation leads to suboptimal investment levels.

Different types of investment may be affected differently by regulation in general and by incentive regulation in particular. Investment in cost reduction and replacement investment, for example, may be positively affected by price-cap or yardstick regulation (Borrmann and Brunekreeft, 2009). This would hold to the extent that regulated firms can keep the benefits from cost reductions in the form of higher profits. In contrast, investment in quality improvements may suffer under these types of regulation because lower quality is a substitute for price increases above the cap or benchmark (Armstrong, Cowan and Vickers, 1994; Kwoka, 2009). However, quality improvements may increase sales so that empirical effects tend to be inconclusive. For example, Banerjee (2003) finds neutral or positive quality effects from moving to price-cap regulation in telecommunications retail markets. ${ }^{3}$

Investment in new products and services can be particularly characteristic of some network industries, such as the telecommunications sector (in the time of digital convergence). Regulation here constrains the upside opportunities. This tends to have less importance for end-user regulation, because it rarely exists for such products (such as

\footnotetext{
${ }^{3}$ The survey by Sappington (2005a) on regulation of service quality cites mixed results from the empirical literature, but is itself largely restricted to theoretical findings.
} 
broadband internet access). It holds, however, for the regulation of new bottleneck inputs (essential facilities). In contrast, incentive regulation may be more compatible with legacy infrastructure investment by an incumbent. Here the investment problem not only concerns the incumbent's investments but also the investment of alternative competitors in complementary infrastructure and in bottleneck bypass.

In principle, regulation can have ambivalent investment effects.

For at least two basic reasons regulation can enhance and accelerate investment (in bottleneck or bottleneck bypass infrastructure). First, by helping to lower the price of the output, regulation increases the demanded output quantity and consequently the capacity required to produce this output. Second, successful bottleneck regulation leads to enhanced competition, which fires up the race for new bottleneck investment between incumbent and entrants (by creating entrants with less of a cannibalization problem than the incumbent).

For at least two other reasons regulation can reduce and retard investments. First, regulation lowers the expected investment returns, going along with increases or decreases in risks. This works via the truncation of uncertain investment outcomes that are caused by price constraints. Investment risks are thereby shifted from consumers and the access seekers to the regulated firm. In principle, this truncation can be at least partially compensated by an increased WACC (and therefore higher price cap) allowed by the regulator. The second reason for reduced or delayed investment is the regulator's lack of commitment, which we will treat extensively below.

The effects of regulation on investments are the result of incentives and governance. We concentrate on regulated prices as the main regulatory incentive variables. The current regulated price provides a signal for the expected price, which in turn determines output and therefore the required investment to avoid non-price rationing. The price (and resulting quantity) determines revenues for financing investment, where - within some range - a higher price facilitates investment. A regulatory truncation of the price distribution lowers expected returns and affects investment risk. 
We consider (lack of) regulatory commitment as the main regulatory governance variable. Almost always regulators want investment (in fact, too much so!). ${ }^{4}$ However, regulators also want low prices. Because prices are set after investment, the wish for lower prices creates an ex post conflict with the ex ante desire for high investment (Brito et al., 2008). Lack of commitment therefore leads to ex post policies detrimental to investment. Anticipating this (under lack of commitment) the regulated firm will refrain from investing.

The basic reason for the use of incentives is asymmetric information. Under symmetric information the regulator could simply tell the firm what to do. There are two fairly distinct methodological approaches to incentive regulation, the Bayesian and the non-Bayesian approach.

The non-Bayesian approach to price regulation goes back to Baumol $(1968,1982)$, Vogelsang and Finsinger (1979) and Littlechild (1983). It is based on simple principles and aims for welfare improvement, not optimization. It is squarely geared for application, but investments have generally not been addressed explicitly in this literature. In contrast, the Bayesian approach, initiated by Baron and Myerson (1982) and Laffont and Tirole $(1986)^{5}$ uses a principal-agent framework that allows for full constrained welfare optimization. It is in general not directly applicable, but addresses investment incentives via commitment. The qualitative insights of this approach are usable for the nonBayesian approach taken in this paper. ${ }^{6}$

The strength or power of incentives is measured by the percentage of cost reductions the firm may keep or of cost increases that it may have to suffer (Laffont and Tirole, 1993). Under strong incentives the firms keep/suffer a high percentage, while under weak incentives they keep/suffer a low percentage. As we show below (in Section 3), the power of incentives is quite separate from the tightness of regulation (which is more

\footnotetext{
${ }^{4}$ See, for example, the European Commission staff document on the review of the EU Regulatory Framework for electronic communications networks and services, which measures successful telecommunications policies in member states by the amount of telecommunications investments undertaken. Available at http://ec.europa.eu/information society/policy/ecomm/doc/library/public consult/review/staffworkingdocu ment_final.pdf.

${ }^{5}$ For penetrating surveys see Laffont and Tirole (1993) and Armstrong and Sappington (2007), who also survey non-Bayesian mechanisms.

${ }^{6}$ For a critique of the Bayesian approach, see Vogelsang (2006).
} 
related to the participation constraint for the firm). Tightness refers to the (economic or excess) profit rate that the regulator is conceding to the firm in case normal expectations are fulfilled. Tight regulation refers to a low or zero expected profit rate and usually is associated with a low regulated price. Conversely, soft regulation refers to a high expected profit rate and usually a high regulated price. Intermediate regulation would lie between tight and soft regulation.

The power of incentives is closely related to the risk that the regulated firm is bearing. Different types of price regulation can with some caution be ranked by the risks/incentives they provide for the firm. Rate-of-return regulation and other cost-plus regulations generally provide low risk and weak incentives. Profit-sharing regulation is associated with medium risk/incentives. Price-cap regulation as the next step carries medium to high risk/incentives. In the list, yardstick/benchmarking regulation (including engineering cost models) comes up with the highest risk/strongest incentives. While these are ranked from low risk/weak incentives to high risk/strong incentives, the regulator can make compensating adjustments either through incentive-mitigating measures, such as true-ups from time to time, or through adjusting the tightness of regulation.

In order to assess the effects of regulation on investment we concentrate on two types of beneficiaries of regulation and two types of infrastructure investment.

Regulation can either concern provision of services to end users or access of alternative providers to competitive bottlenecks. Here "bottleneck" is used in the sense of an essential facility, which is a necessary input (fixed proportions) that is owned by an incumbent and cannot be duplicated economically by potential entrants (natural monopoly property). Examples of such bottlenecks include transmission and distribution networks in electricity that would have to be used by competing electricity generators to reach potential customers. They also include local loops in fixed telephone networks that have to be used by local and long-distance carriers to originate and terminate calls.

End-user regulation generally tries to prevent exploitation of consumers and shall lead to competitive prices, while bottleneck regulation tries to enhance competition and prevent foreclosure. Both types of regulation could prevent predation. 
The relevant investment can concern competitive bottlenecks or complementary infrastructure downstream or upstream of the bottleneck. In both cases the investor can either be the regulated incumbent or unregulated competitors.

\section{Literature review}

\subsection{End-user regulation}

A growing literature has emerged recently on the relationship between investment and regulation. This has, however not yet led to very clear results. ${ }^{7}$ Unsurprisingly, the early work has concentrated on rate-of-return regulation, while the newer work emphasizes incentive regulation, price caps in particular, and sometimes compares rateof-return regulation (or other types of cost-based regulation) with price caps. We will here concentrate more on theoretical than on empirical contributions, largely because a large part of the empirical work appears to be quite weak and driven by partisan considerations. ${ }^{8}$ While the conventional wisdom is that rate-of-return regulation is likely associated with excessive investment, the literature is actually more differentiated. First, it has been know since Averch and Johnson (1962) that the excessive investment result only holds for an allowed rate of return ' $\mathrm{s}$ ' between the monopoly rate ' $\mathrm{m}$ ' and the cost of capital ' $\mathrm{r}$ ' $(\mathrm{r}<\mathrm{s}<\mathrm{m})$. In the more realistic model formulation of Bawa and Sibley (1980) a higher allowed rate than $\mathrm{m}$ would lead to no change in investment compared to no regulation or even to reduced investment. Similarly, a rate of return at $s=r$ would lead to efficiency and $\mathrm{s}<\mathrm{r}$ would lead to underinvestment. The original results of Averch and Johnson were qualified

- by considerations of regulatory lag (Baumol and Klevorick, 1970; Bailey and Coleman, 1971). Such a lag would generally reduce the overcapitalization bias but could also lead to undercapitalization (Joskow and MacAvoy, 1975). With an endogenous lag that decreases in the deviation between actual and allowed

\footnotetext{
${ }^{7}$ For reviews of the literature on regulation and investment see Guthrie (2006) and, specifically for the case of broadband investment, Cambini and Jiang (2009).

${ }^{8}$ This definitely shines through in Cambini and Jiang (2009). They have only found two papers on end-user regulation and telecommunications infrastructure investment (Greenstein, McMaster and Spiller, 1995, and $\mathrm{Ai}$ and Sappington, 2002). In contrast, they list 23 works on access regulation and infrastructure investment, but quite a few of these are either not really empirical (simulations and numerical examples) or financed by incumbents or organizations of alternative competitors. None of these 23 papers has been published in a top economics journal.
} 
rate of return efficiency can be reached even if the allowed rate exceeds the cost of capital (Bawa and Sibley, 1980).

- by different valuations of the rate base (largely historic costs versus replacement costs). Evans and Guthrie $(2005,2006)$ note that replacement cost valuation can expose the regulated firm to asset price risks.

- by addressing a used-and-useful criterion for investments to be included in the rate base (Gilbert and Newbery, 1994; Newbery, 2000). Gilbert and Newbery, in particular, argue that rate-of-return regulation with a used-and-useful criterion (as practiced?) is likely to lead to an efficient amount of investment. In contrast, Égert (2009) argues that the used-and-useful criterion introduces uncertainty into the regulatory process that would lead to underinvestment or a biased type of investment. This is also implied by Evan's and Guthrie's (2006, 2006) critique of the use of optimized replacement costs that do not include excess capacity for the case of demand uncertainty. Such excess capacity would not appear to be "used and useful" in states of low demand and would therefore be disqualified for inclusion in the rate base by regulators (Baumol and Sidak, 2002).

Thus, it appears that the effects of rate-of-return regulation on investment would heavily depend on the way it is actually handled by regulators and courts.

A positive relationship between price-cap regulation and investment was established early on by Cabral and Riordan (1989) for the case of cost-reducing investments. This was, however, limited to the full commitment case (infinite time horizon) and to a specialized type of investment. Later work came to much more qualified conclusions, finding that positive investment effects would depend on the length of commitment (Biglaiser and Riordan, 2000) and on the level of the cap (Nagel and Rammerstorfer, 2008; Roques and Savvas, 2006 and 2009). These latter works use a real-option approach so that the price cap triggering optimal investment is highly dependent on sunkness and uncertainty. Generally, overestimating the cap seems to have less dire consequences for investment than underestimating it. Dobbs (2004) finds that, because of the truncation problem inherent in capped prices, underinvestment would arise even under optimal price caps and would lead to non-price rationing (= deteriorated quality). All this work, just 
like in the case of rate-of-return regulation, strongly suggests that the investment effects of price-cap regulation clearly depend on the way the regulation is handled in practice.

Sobel (1999) finds that yardstick regulation, by using information on low-cost firms (ex post), may prevent optimal investment (ex ante) of regulated firms. Borrmann and Brunekreeft (2009), in a sunk-cost model under certainty, show that yardstick regulation leads to postponement of expansion investment (relative to the social optimum, though not necessarily relative to unconstrained profit maximization), while it accelerates replacement investment.

The work on the relationship between profit-sharing regulation and investment seems to be restricted to Panteghini and Scarpa (2003) and Moretto, Panteghini and Scarpa (2008). ${ }^{9}$ They find that under uncertainty straightforward RPI-X price caps lead to higher investment than profit sharing regulation. While insightful these papers seem to derive their results from their asymmetric definition of profit sharing, where "sharing" only occurs if the profits exceed a certain level. Thus, profit sharing does not reduce the firm's risk because it only happens in the good states of the world. Rather, it prevents the firm from reaping the upside potential in the good states that would be necessary for compensating downside risks in bad states. This result has potential practical importance, because asymmetric profit sharing is actually used by some regulators. It is also highly intuitive but it says very little about the effect of real, i.e. symmetric, profit sharing, where the firm would have some downside protection. Such symmetric profit sharing would have price caps and rate-of-return regulation as polar cases with price caps as zero sharing and rate-of-return regulation as $100 \%$ sharing.

Interestingly, the two main empirical papers on the relationship between different types of regulation and investment in telecom network modernization show larger investments in incentive regulation regimes (price caps in particular) compared to rate-ofreturn regulation (Greenstein et al., 1995; Ai and Sappington, 2002). This may be due to the fact that, in its practical application, incentive regulation in the U.S. was quite soft to begin with.

\footnotetext{
${ }^{9}$ In addition, Weisman (2005) considers the relationship of profit-sharing regulation with investments in quality.
} 


\subsection{Access price regulation}

The theoretical literature on the relationship between access price regulation for monopolistic bottlenecks and investment is quite diversified regarding the issues addressed. $^{10}$

A sizeable part of the literature is mainly concerned with the effect of the regulated access price on the incentive of the bottleneck owner/incumbent to invest in new or expanded infrastructure, independent of the effect on potential alternative competitors. The concern here is predominantly with access prices based on TELRIC/LRAIC. ${ }^{11}$ The main argument is that access prices/prices for unbundled network elements that do not cover all costs of investment would stifle investments. Proponents of the TELRIC/LRAIC approach argue that by definition these two cost concepts include all costs of expansion investments in new infrastructure. Thus, any shortfall in (expected) coverage of investment costs would have to come from cost measurement errors or mistakes in the underlying models. Potential errors could come (a) from measurement of the required capacities under lumpiness paired with uncertain/fluctuating demand and (b) from measurement of costs of capital (WACC) under sunkness. Opponents of the TELRIC/LRAIC approach here argue that the regulators systematically err by not including enough reserve capacities and by making no WACC adjustments for real options. Comacho and Menezes (2009) show that failure to include real options of delay (under an ECPR approach) leads to sub-optimal investments. In contrast, their alternative of using an Option to Delay Pricing Rule (OPDR) essentially requires the regulator to be fully informed about market conditions and thereby be able to implement the optimal end-user prices directly. In my view, regulators probably err in the wrong direction by not including the value of real options in the calculations for costs of capital (WACC) for TELRIC/LRAIC.

Another concern for investment incentives of the incumbent could come from spillover effects of the investment on the demand for entrants' services. Technology upgrades, from which entrants would benefit, would fall under such spillovers.

\footnotetext{
${ }^{10}$ We leave out (2-way) interconnection regulation, which seems to be restricted to telecommunications. This leaves out, in particular, the termination issue. See Vogelsang (2003).

${ }^{11}$ TELRIC stands for "Total Element Long-Run Incremental Cost", while LRAIC stands for "Long-Run Average Incremental Cost". Both of these are usually measured in analytical cost models.
} 
Incumbents would have reduced incentives for such investments if they have to provide access at prices that are less profitable than their downstream prices (Kotakorpi, 2006).

A second large part of the access-related literature addresses the incentive effects of unbundling obligations on competitors' investments. This literature specifically centers on the stepping-stone or ladder-of-investment hypothesis (partially due to Cave and Vogelsang, 2003). The ladder-of-investment hypothesis claims that entry by alternative providers in a market dominated by an incumbent is hindered by the necessity to acquire assets with a range of bottleneck properties. As time goes by, as entrants learn and as they grow in size (thereby availing themselves of economies of scale), they can climb an investment ladder with increasing bottleneck properties. Foreseeing that development the regulator should begin by forcing the incumbent to make all bottleneck inputs available at attractive prices thereby enabling entry. However, the regulator should commit to reducing the attractiveness of regulated access over time, beginning with inputs with less bottleneck properties. This is meant to increase incentives for alternative providers to actually invest in assets with increasing bottleneck properties because regulated access becomes less and less attractive.

The ladder-of-investment hypothesis has been embraced by European telecommunications regulators but has been criticized in the literature. Burreau and Doğan (2006) point out in a theoretical model that with increasing availability of alternative or bypass infrastructure the incumbent bottleneck owner would voluntarily provide bottleneck access at increasingly attractive terms for the alternative competitors, thereby retarding bypass. Thus, according to them, instead of increasing regulated access prices as bypass becomes more and more available, the regulator should prohibit unbundled access, once bypass becomes economical because otherwise bypass would come too late. The authors claim that, for the same reason, regulatory sunset clauses would not help. ${ }^{12}$ However, a major problem with both an application of the ladder-ofinvestment approach and with the Bourreau and Doğan suggestion is that the regulator will generally not know, when bypass is sufficiently feasible and that this feasibility will differ locally across the country.

\footnotetext{
${ }^{12}$ Avenali et al. (2010), in what appears to be the first theoretical model of the ladder-of-investment hypothesis, show that under their assumptions the Bourreau and Doğan assessment of the ladder-ofinvestment approach and of sunset clauses would not hold.
} 
A counter-argument to the ladder-of-investment approach similar to that raised by Bourreau and Doğan can be derived from the inclusion of real options in the incumbent's access costs. Accordingly, for sunk bottleneck access the risk of bypass would justify initial surcharges on conventional TELRIC/LRAIC calculations but these would no longer be feasible, once bypass occurs, thus leading to a declining path of access prices.

The ladder-of-investment approach assumes that bypass is based on an extension of investments in the same legacy technology of the incumbent. In reality, however, it usually occurs through a new technology or improvement of another technology that is different from the legacy infrastructure of the incumbent. Examples of the former could be FTTH or VDSL, ${ }^{13}$ through which the bypass opportunities may deteriorate. An example of the latter is a cable TV network that competes with the telephone/DSL network of the incumbent and of entrants using the incumbent's technology. The ladderof-investment approach does not work here because (a) the entrants cannot effectively duplicate the incumbent's local loops and (b) the cable TV company investments may be jeopardized by any boost given to the incumbent by selling access to the entrants. In a way, the entrants climb the wrong ladder in this case.

Overall, the working of the ladder-of-investment approach appears to be strongly depending on the circumstances of the industry as well as on the way it is implemented by the regulator. ${ }^{14}$

A third part of the access-related literature concentrates on the interaction of the effects on incumbents and entrants. Gans (2001), for example, suggests an optimal twopart access tariff that ensures optimal investment of a regulated firm that has to immediately grant access to this new infrastructure to rivals. Thus, the formula both provides for the optimal timing of investment and helps preempt competing investments by potential rivals.

\footnotetext{
${ }^{13}$ FTTH stands for "Fiber To The Home", while VDSL stands for "Very-High-Data-Rate Digital Subscriber Line" and can usually be seen as "Fiber To The Neighborhood".

${ }^{14}$ The empirical literature cited by Cambini and Jiang (2009) on this subject, for example, appears to be fairly blind to subtle aspects of this approach. If, for example, Hazlett and Bazelon (2005) find that low UNE-P rates in the U.S. are associated with a decrease in CLEC-owned telephone lines that does not contradict the ladder-of-investment approach. Because a large part of the network elements covered by UNE-P are clearly replicable they should actually be priced highly in order to spur CLEC investment. In contrast, unbundled loops should be priced lowly. UNE-P stands for the platform of unbundled network elements that allowed entrants to offer network services almost without having any own network infrastructure.
} 
Several papers deal with incumbent and entrant investment in models that capture a new industry, in which two firms have to decide, which one will invest first and in which access regulation has been established before (Hori and Mizuno, 2006; Vareda and Hoernig, 2007). Here, low access charges usually (but not always) retard both the incumbent's (initial) and the entrant's investments, while high access charges lead to preemptive strategies.

The empirical literature on both incumbent and entrant investment includes Grajek and Röller (2009), whose estimations relate to telecommunications investments in fixed networks. They find a negative relationship between access regulation and individual incumbents' and entrants' investments, although total entrants' investments increase. In addition, incumbents invest more in response to entrants' investment increases. The effect of regulation is found only, when controlling for the endogeneity of access regulation. In particular, regulators are found to tighten regulation in response to increased investments by incumbents.

\section{Regulation Under Full Commitment}

\subsection{The case for intermediate regulation}

My approach to regulation and investment can be characterized as follows. The literature on the relationship between regulation, investments and innovation suggests many different case-specific outcomes. This to me suggests ample employment opportunities for economists as advisors to regulators, incumbents, alternative competitors and consumer groups. Keeping the cases apart and deriving case-specific regulations is highly information-intensive and may be subject to moral hazard and adverse selection on the side of the regulators. I have dealt with regulators in a number of countries and have again and again been impressed by their knowledge, skills and ethics. Nevertheless, there are things that regulators cannot and probably should not do. Among them is taking responsibility for infrastructure investment decisions and for innovations. My approach is to use simple economics and insights from the literature for extracting some fairly general properties and to come up with a few rough-and-ready rules. They may do injustice to the individual case but are more likely to be feasible for 
implementation and less subject to commitment problems than more specific casedependent rules.

Consider first the relationship between the regulated (bottleneck) price and the incumbent's infrastructure investment, as depicted in Figure 1. The simplified view illustrated by the investment function (correspondence) combines two constraints on investment. The shape of the function is assumed to be affected by cost and demand risks. In particular, the risk results in a thick corridor in the horizontal portion. This leads to asymmetric effects of tight vs. soft regulation. Tight regulation can potentially lead to high investment, due to the implied large demanded quantity. However, it could also lead to zero investment if the regulated firm (or the capital market) views the investment as being too risky at that price. In contrast, a price increase to the level of soft regulation implies no regulatory risk (under full commitment), but leads (for sure) to fairly small investment. Intermediate regulation leads to substantially higher investment that can also be virtually assured. The view exposed in this argumentation contrasts with most of the literature, which largely neglects any demand-side effects from lower prices.

Figure 1: A simplified view of infrastructure investment as a function of price: Soft vs. tight regulation

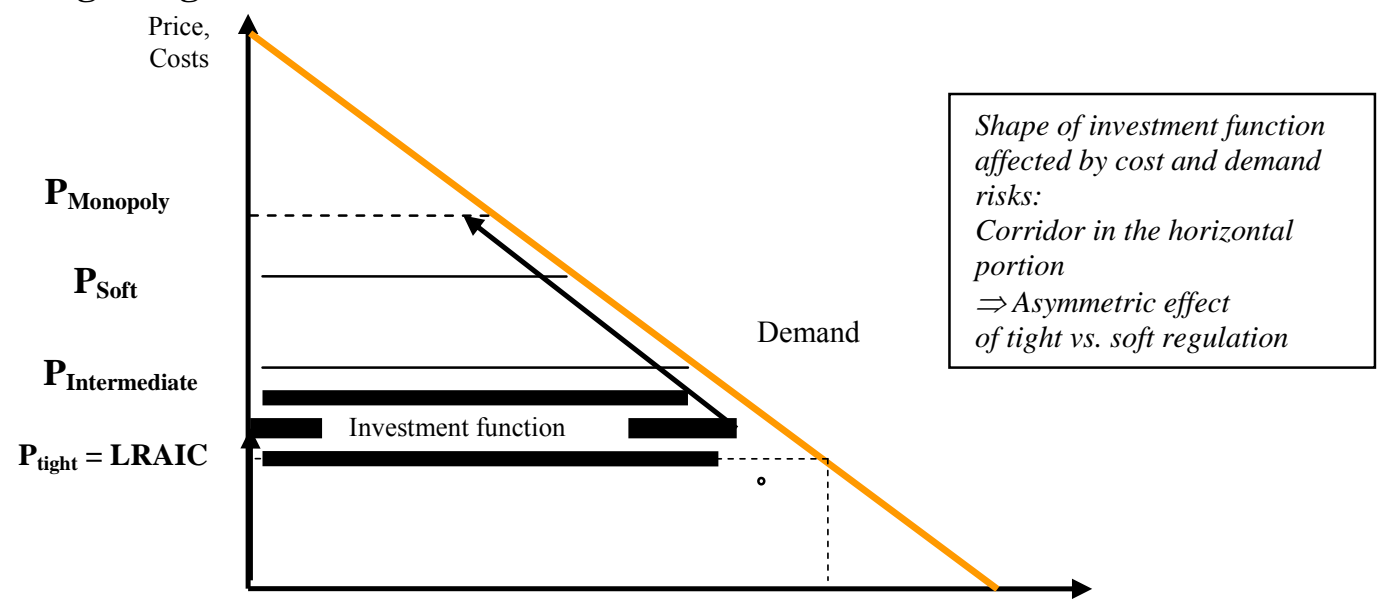

Investment

In Table 1 we differentiate between several types of infrastructure for investment purposes. Bottleneck infrastructure (to which the access is regulated) could either be legacy and innovative infrastructures of incumbent (column 1) or bypass infrastructure by 
competitors (column 2). The latter would not strictly represent bottlenecks, which by definition could not economically be duplicated by others. However, the regulatory restructuring and reform movement is based on the premise that new technical and market developments can potentially abolish or reduce bottlenecks over time and that this can be helped by regulation. A low regulated price for bottleneck access could have facilitated competitive entry. However, a continued low access price can discourage entrants from investing in bottleneck bypass, while an increased access price could induce bypass investment. This is the ladder-of-investment aspect (Cave and Vogelsang, 2003; Cave, 2006). In addition, the entrants may be more likely to invest in new types of bottleneck infrastructure, while the replacement effect of such infrastructure may prevent the incumbent from doing so (Bourreau and Doğan, 2004; Hori and Mizuno, 2009). Low access prices may therefore initially increase both competition for the market and competition in the market. However, the increased competition in the market will make competition for the market unattractive. The next type of infrastructure concerns investments downstream or upstream of the bottleneck and is generally not regulated. This infrastructure can again be that of a vertically integrated incumbent (column 3) or it could be alternative competitors' infrastructure (column 4). The infrastructure downstream or upstream of the bottleneck is by assumption no bottleneck (otherwise it would be included there) and therefore basically similar for both the vertically integrated incumbent and the competitors. ${ }^{15}$ The competitors will generally have newer infrastructure, though. Last, there could be access-related infrastructure.

Table 1: Effects of tightness of bottleneck regulation on infrastructure investment in absence of retail regulation

\begin{tabular}{|l|l|l|l|l|}
\hline $\begin{array}{c}\text { Investment } \\
\text { Type } \\
\text { Regulation }\end{array}$ & $\begin{array}{l}\text { Incumbent } \\
\text { Bottleneck }\end{array}$ & $\begin{array}{l}\text { Competitive } \\
\text { Bypass (Make } \\
\text { or Buy) }\end{array}$ & $\begin{array}{l}\text { Incumbent } \\
\text { Downstream }\end{array}$ & $\begin{array}{l}\text { Competitive } \\
\text { Downstream }\end{array}$ \\
\hline tight & $-(+)$ & $\begin{array}{l}- \\
\text { Sappington: 0 }\end{array}$ & $-(+)$ & + \\
\hline intermediate & + & $\begin{array}{l}0 \\
\text { Sappington: } 0\end{array}$ & + & 0 \\
\hline soft & $+(-)$ & $\begin{array}{l}+(-) \\
\text { Sappington: } 0\end{array}$ & $+(-)$ & - \\
\hline
\end{tabular}

\footnotetext{
${ }^{15}$ The incumbent, however, may be able to shift costs between the two production stages and thereby gain a competitive advantage. See Laffont and Tirole (2000).
} 
Figure 1 provides the basis for the "Incumbent Bottleneck" column in Table 1. Accordingly, tight regulation can only have a positive effect on investment if there is no cost uncertainty. Otherwise, tight regulation would choke investment. In contrast, soft regulation has a positive effect at high uncertainty and inelastic demand, but can have substantial negative effects if uncertainty is less and demand more elastic. Intermediate regulation would balance the two tendencies.

The second column indicates that competitive bypass investment is discouraged by tight bottleneck regulation, because access to the incumbent's bottleneck is then cheaper than bypass. In contrast, soft regulation makes bypass attractive if bypass is fully possible. Intermediate regulation makes bypass attractive if bypass is partially possible. This line of reasoning about bypass investment is questioned by Sappington (2005b), who shows in theoretical models that the tightness of bottleneck regulation is just compensated by the incumbent's competitive reactions downstream. This means that tight regulation is accompanied by aggressive downstream competition, while soft regulation would be accompanied by more collusive behaviour. As a result, the alternative competitors will only invest in bottleneck bypass if they can do so more cheaply than the incumbent and that will be independent of the regulated bottleneck access charge. The question if this behaviour is restricted to Sappington's model assumptions or if it holds more generally has been analyzed by Mandy (2009), who finds that input prices generally do matter for the efficient make-or-buy decision and that efficient decisions can be induced by pricing the input access at the entrant's marginal cost (of bypass). This may, however, leave the entrants out in the cold if they cannot economically duplicate the bottleneck facility.

Because of mostly fixed proportions between bottleneck and complementary investments the last two columns of Table 1 simply parallel the first two. Accordingly, tight bottleneck regulation increases downstream output and downstream investment overall. However, the distribution of investment between incumbent and competitors may depend on their relative efficiency downstream. A relatively more (less) efficient incumbent will invest more (less). 
Table 2 displays effects of the tightness of end-user regulation on infrastructure investments. Here the results for competitive bypass and downstream investments are opposite to the case of bottleneck regulation, because - in contrast to the latter - end-user regulation does not benefit but rather tends to handicap competitors. Tight end-user regulation of the incumbent acts like increased competition in the market and therefore makes competition for the market less attractive. As a result, entry will be reduced and exit increased. There is a possibility though that (in an oligopolistic setting) alternative competitors already in the market may expand when end-user regulation tightens up. The effects of soft end-user regulation would then just be the reverse.

The effects of tightness of end-user regulation on the incumbent's investment are quite similar to those of bottleneck regulation except that there are additional effects from the way end-user regulation affects alternative competitors. The negative effect of tight regulation on the incumbent's investment may therefore be somewhat buffered by the reduction in the number of competitors and the positive effect of soft regulation may be somewhat neutralized by increased competition.

Table 2: Effects of tightness of end-user regulation on infrastructure investment

\begin{tabular}{|l|l|l|l|l|}
\hline $\begin{array}{c}\text { Investment } \\
\text { Type } \\
\text { Regulation }\end{array}$ & $\begin{array}{l}\text { Incumbent } \\
\text { Bottleneck }\end{array}$ & $\begin{array}{l}\text { Competitive } \\
\text { Bypass (Make } \\
\text { or Buy) }\end{array}$ & $\begin{array}{l}\text { Incumbent } \\
\text { Downstream }\end{array}$ & $\begin{array}{l}\text { Competitive } \\
\text { Downstream }\end{array}$ \\
\hline tight & $-/+$ & $-(+)$ & $-/+$ & $-(+)$ \\
\hline intermediate & + & 0 & + & 0 \\
\hline soft & $+/-$ & $+(-)$ & $+/-$ & $+(-)$ \\
\hline
\end{tabular}

On the bottleneck level tight regulation appears to be best for upstream/downstream investment and soft regulation best for bottleneck and bypass investment. The best overall approach to end-user regulation depends on the relative weight and relative sunkness of bottleneck infrastructure vs. other infrastructure. Intermediate regulation appears to be the generally best compromise. On the end-user level soft/intermediate regulation virtually dominates for all types of investment. Soft regulation enhances competition as long as foreclosure can be avoided via bottleneck regulation. Soft 
bottleneck regulation can therefore increase price-squeeze problems. This assessment is in line with the view that end-user markets should be deregulated first. ${ }^{16}$

\subsection{Intermediate regulation as incentive regulation}

We have seen that intermediate or even soft regulation may provide better investment incentives than tight regulation. Incentive regulation, however, seems to call for a tight approach. How then can soft regulation provide efficiency incentives? ${ }^{17}$ Consider different types of incentive regulation.

Soft profit-sharing regulation could mean

(a) a soft definition of (excess) profits. Such an approach to softness would preserve incentives, because it would preserve the extent to which the regulated firm remains a residual claimant.

(b) more ( $=$ a higher percentage of $)$ sharing. This would mean a move in the direction of rate-of-return regulation. Such a move reduces incentives.

(c) asymmetric sharing in favor of the regulated firm, meaning that the firm would suffer a smaller share of any losses and gain a larger share of any profits. ${ }^{18}$ Such softness would likely lead to overinvestment, because the firm would face reduced risks.

Soft price-cap regulation means a higher cap. Generally, the cost-reducing incentives are deemed largely independent of the price-cap level so that incentives would be preserved. In contrast, investment incentives would be increased (Roques and Savvas, 2006, 2009; Nagel and Rammerstorfer, 2008). There would be an allocative inefficiency, though. Under end-user regulation part of this inefficiency would (in the long run) be balanced by increased competitive pressure. Under bottleneck regulation part of the reduced downstream competition would be balanced by bypass incentives.

Regulation based on analytical cost models (LRAIC or TELRIC) provides intrinsic efficiency incentives if the models are independent of the incumbent's actual costs. Soft

\footnotetext{
${ }^{16}$ We have in this simple analysis not considered any interactions between bottleneck regulation and enduser regulation.

${ }^{17}$ In the following we assume that firms are maximizing profits and therefore fully respond to incentives instead of incurring X-inefficiency.

${ }^{18}$ This is the opposite of the sharing studied in Panteghini and Scarpa (2003) and Moretto et al. (2008), which led to underinvestment.
} 
regulation here could be implemented via a higher built-in rate of return (which could be more than a simple risk surcharge). In particular, regulators could include a surcharge for real options in case of sunk assets (err in favor of including real options). There could be additional uncertainty from the replacement cost approach used in such models (Evans and Guthrie, 2005).

Benchmarking (yardstick) regulation is usually applied in reference to an actual efficiency frontier provided by a set of firms. While regulated rates on the frontier would represent tight regulation, intermediate or soft regulation could allow for a pre-set distance from the efficiency frontier. Also, under soft regulation the rate could be based on the cost average of the firms rather than on the frontier. Efficiency would be preserved to the extent that the benchmark is independent of the particular regulated firm's behavior.

Last, under Bayesian regulation one could allow for a positive (economic) profit at the participation constraint. This could lead to similar productivity incentives but higher expected profits.

Thus, with the exception of some forms of profit sharing soft/intermediate regulation appears to be fully compatible with providing cost-reducing/productivity-enhancing incentives.

However, what is the yardstick for intermediate regulation and how can it be implemented? Criteria for tight regulation can usually be established with some precision and therefore be framed in regulatory rules/laws. In contrast, soft/intermediate regulation may require regulatory discretion. ${ }^{19}$ Verifiable criteria for "intermediate" are hard to come by. One could therefore establish a two-step procedure.

Step 1 would involve establishing and applying criteria for applicability of tight vs. soft/intermediate regulation, keeping in mind that soft/intermediate resembles light regulation and can therefore be viewed as a step in the direction of deregulation. For example, under the ladder-of-investment approach, soft/intermediate regulation may be inappropriate in markets with routine (small, short-run) investments without bypass opportunities. In such markets, any move towards deregulation would be unwarranted, and surcharges on the firm's cost of capital would be unnecessary for triggering

\footnotetext{
${ }^{19}$ The commitment problem is treated extensively below.
} 
investments. In contrast, softer regulation would be justified under increased uncertainty, increased sunkness and increased bypass possibilities.

Step 2 would then involve choosing a specific type of soft/intermediate regulation, given that it has first been established as necessary/appropriate. Examples of intermediate regulation that have been codified include a combination of ex post regulation and the application of competition law criteria in the German Telecommunications Act of 2003. This approach gives the incumbent some flexibility because he/she does not have to get permission first before setting prices. At the same time, the criterion for regulatory intervention is not based on efficient costs (which are the criterion for ex ante regulation in the same law) but rather on non-abusive prices. ${ }^{20}$ Another approach that would be applicable in case of reasonable downstream competition is the Efficient Component Pricing Rule (ECPR). ${ }^{21}$ Benchmarking based on averages rather than on frontier costs would be another example for intermediate regulation. This would be a pricing approach where clear differentiation of criteria is possible. A radical approach on the governance level would be the choice of a pro-industry regulator (Evans, Levine and Trillas, 2008).

As a general rule, at the same expected returns, the stronger the power of incentives, the greater the risk that the firm faces. ${ }^{22}$ As a result, regulatory mechanisms with stronger incentives will be associated with higher costs of capital for the regulated firm. In that sense, regulation may have to be softer for inducing investments the stronger the incentives the regulation provides. My reading from the empirical and theoretical literature is that, initially, the move from rate-of-return regulation to incentive regulation or from state-owned ("unregulated") to privatized incentive-regulated enterprises has involved quite soft regulation. This happened both because of inexperience and cautiousness of the regulators, who are highly afraid of service interruptions, and because of large potentials for efficiency improvements. After some time, this cautiousness and potential productivity improvements wear out so that regulation becomes tighter. That

\footnotetext{
${ }^{20}$ Non-abusive prices include normal (workably-competitive) markups on the firm's actual costs (rather than prices equal efficient costs).

${ }^{21}$ Kotakorpi (2006) argues that incumbents' investments in infrastructure with demand spillovers to entrants would only be efficient if the incumbent can earn as much from selling access as from selling downstream. This would suggest using the ECPR but may, at the same time, favor some downstream regulation.

${ }^{22}$ Risk may also have increased through other aspects of regulatory restructuring, such as vertical separation or pro-competitive policies (Kwoka, 2009).
} 
may be the reason why Greenstein et al. (1995) and Ai and Sappington (2002) found positive relationships between the introduction of incentive regulation and investment. It may also be the reason why incumbents today complain about the lack of investment incentives. This would suggest a return to "softer" regulation.

\section{Ordinary investments vs. innovative investments}

We now want to contrast the effects of regulation on ordinary investments vs. on innovative (infrastructure) investments, which are particularly relevant for the telecommunications sector. ${ }^{23}$

Ordinary investments concern maintenance, replacement or expansion of legacy infrastructure. From a regulatory perspective they are characterized by fairly well-known costs and well-known demands so that (analytical) cost models developed in the past could be fully applicable. Nevertheless, some problems of sunk costs remain so that a surcharge for real options may need to be added to the WACC. Unbundling and competitive network access is feasible (e.g., in telecommunications), leading to sufficient downstream competition and downstream deregulation.

In contrast, innovative investments concern new types of infrastructure. The costs are little known and highly uncertain. Because they are usually also associated with new enduser products (at least in telecommunications) their demand is hard to assess and there is a risk of low penetration and low capacity utilization. Initially, there will be high average costs based on the large sunk costs of getting the incumbent started. Penetration pricing below costs can help the start but may be hard to distinguish from foreclosure and predation. Unbundling and access regulation are inherently difficult because of the lack of experience with the new technology (Faulhaber, 2003). At the same time innovative infrastructure is more likely a case of symmetry in starting positions between incumbent and other market players so that a possible race for investment could ensue.

The question arising from all of this is if innovative investments should be a case for deregulation (or for lack of regulation to begin with). This begs the further question how

\footnotetext{
${ }^{23}$ Kwoka, in a mail to the author, points out that the quality may be more important than innovation for the functioning of incentive regulation. Both quality and innovation appear to be problems that incentive regulation cannot easily deal with. For innovation the question is if deregulation is called for or if WACC adjustments suffice. For quality the question is if incentive regulation of prices has to be complemented by specific quality regulation. For more on the latter see Kwoka (2009).
} 
the decision between regulation and no regulation should be made. Since the regulation in question is based on bottleneck/essential facilities properties and therefore market power, deregulation or no regulation means that the particular market would be governed solely by competition policy. From a normative perspective, deregulation is therefore appropriate if competition policy (alone) is providing a higher level of welfare than regulation (with or without additional competition policy).

The decision between regulation and competition policy requires a comparative evaluation of the two in solving the (bottleneck) problem at hand. This in turn requires an assessment of the main properties of regulation and competition policy. Table 3 provides the characteristic properties of regulation with their advantages and drawbacks. ${ }^{24}$ All three specific characteristics (ex ante remedies, specialized agency and prescriptive intervention) tend to lead to strong and preventative interventions that can potentially prevent large damages from anticompetitive behavior. At the same time those characteristics reduce the freedom of the incumbent to compete and discover new possibilities.

Table 3: Properties of regulation

\begin{tabular}{|l|l|l|}
\hline Properties of regulation & Advantages & Drawbacks \\
\hline Ex ante remedies & $\begin{array}{l}\text { Immediacy, precision, } \\
\text { dependability, prevention }\end{array}$ & $\begin{array}{l}\text { Reduction of freedom to } \\
\text { compete, too much } \\
\text { intervention }\end{array}$ \\
\hline Specialized agency & $\begin{array}{l}\text { Specialized knowledge, } \\
\text { speed of intervention }\end{array}$ & $\begin{array}{l}\text { Influence of interest groups, } \\
\text { (too little or) too much } \\
\text { intervention }\end{array}$ \\
\hline $\begin{array}{l}\text { Prescriptive intervention } \\
\text { (affirmative duties) } \\
\text { Pricing } \\
\text { Quality }\end{array}$ & $\begin{array}{l}\text { Strong influence on desired } \\
\text { behavior, precision }\end{array}$ & $\begin{array}{l}\text { Reduction of freedom to } \\
\text { compete, inefficient } \\
\text { prescriptions because of } \\
\text { asymmetric information; } \\
\text { too much intervention }\end{array}$ \\
\hline
\end{tabular}

The contrasting characteristics of general competition law are named in the first column of Table 4 . The requirement to show a violation before action is taken makes competition law (alone) inappropriate

- if violations result in large, irreparable damages,

${ }^{24}$ This and the following table are adapted from Holznagel and Vogelsang (2009). 
- if violations are hard to prove,

- if they occur frequently and repeatedly.

In principle, competition law could remain appropriate even under such circumstances if penalties and compensation payments for violations were large enough to prevent such violations and damages (Shavell, 1984). In practice, penalties and compensations are limited and uncertain and therefore insufficient to prevent such violations and damages. Competition policy remedies can also be insufficiently tailored to pricing situations and quality-related violations and can be hard to maintain over time. These properties largely disqualify sole reliance on competition law in situations where incumbents own monopolistic bottlenecks that cannot reasonably be duplicated by alternative competitors and that are necessary for competing in the end-user markets served by the bottlenecks.

Table 4: Inappropriateness of general competition law

\begin{tabular}{|l|l|l|}
\hline $\begin{array}{l}\text { Property of } \\
\text { competition law }\end{array}$ & $\begin{array}{l}\text { Competition law inappropriate } \\
\text { if.... }\end{array}$ & Relevant for... \\
\hline $\begin{array}{l}\text { Requirement to } \\
\text { show violation }\end{array}$ & $\begin{array}{l}\text { Large, irreparable damages } \\
\text { (compensated by large penalties?) } \\
\text { Difficult to prove abuses, e.g. } \\
\text { Denial of access hidden by slowing } \\
\text { down negotiations } \\
\text { Frequent and repeated abuses }\end{array}$ & $\begin{array}{l}\text { Access to monopolistic } \\
\text { bottlenecks } \\
\text { Predation against } \\
\text { competitors }\end{array}$ \\
\hline Inability to set prices & $\begin{array}{l}\text { Lack of comparable markets } \\
\text { Economies of scale and scope } \\
\text { Long duration of intervention in a } \\
\text { changing environment }\end{array}$ & $\begin{array}{l}\text { Access to monopolistic } \\
\text { bottlenecks } \\
\text { Market dominance in access } \\
\text { market } \\
\text { Monopoly in end-user } \\
\text { market }\end{array}$ \\
\hline $\begin{array}{l}\text { Inability of } \\
\text { supervision }\end{array}$ & $\begin{array}{l}\text { Considerable information } \\
\text { requirements } \\
\text { Continuous supervision } \\
\text { requirements }\end{array}$ & $\begin{array}{l}\text { Access requirements } \\
\text { Price regulation }\end{array}$ \\
\hline
\end{tabular}

As tables 3 and 4 show, the choice between sector-specific regulation and general competition policy always involves tradeoffs. These tradeoffs may be strongly affected if investments by an incumbent involve technological change. In particular, the advantages 
of regulation and disadvantages of competition policy will become less relevant if the alternative under regulation is no or insufficient innovation.

There are two arguments for deregulation of or regulatory holidays for innovative infrastructure. First, the patent argument states that you get more innovation from the additional freedom and lack of profit constraint provided by an extended period of no regulation, and that this additional innovation is more valuable than the potential deadweight loss from monopoly pricing. Second, the error argument states that regulation of innovative infrastructure is inherently more complicated than regulation of legacy infrastructure. Also, potential benefits from innovation are much higher than benefits from regulation. The error from false and distorting regulation is therefore more likely and more severe than in the case of legacy infrastructure. These arguments do not mean that the potential for innovation automatically calls for the absence of regulation. ${ }^{25}$ However, the cards would be more heavily stacked against regulation the more important innovation becomes.

Thus, how can one distinguish ordinary from innovative investments? One potentially workable approach is the notion of "emerging markets" under the EU communications framework. This notion is based on the property that "the three-criteria test cannot be applied." The three-criteria test stipulates that a dominant firm in a market defined by competition law criteria should be regulated if (1) there are high and stable barriers to entry, (2) competition is not expected to increase in the foreseeable future and (3) the first two market failures cannot be adequately dealt with through competition policy instruments. These last three criteria have to be met cumulatively (i.e., all have to hold together). The non-applicability of the three-criteria test essentially means that either a market cannot (yet) be defined for the product in question or that one cannot measure if there are high and enduring entry barriers or if competition is likely to be effective or if competition policy could effectively deal with those entry barriers or lack of competition. This notion of emerging markets takes an extremely narrow view of innovations and, to the best of my knowledge, has as of yet not shown any innovation to qualify as an

\footnotetext{
${ }^{25}$ Competition policy has to deal with its own potential error costs. For the case of innovations, see Manne and Wright (2009).
} 
emerging market. A weaker concept might be the creation of a new market in the competition policy sense.

\section{Long-term Investment and Variable Commitment}

\subsection{A Two-period framework}

The importance of commitment for incentive regulation has been emphasized in the literature for a long time. In particular, Laffont and Tirole's (1993) long treatise of incentive regulation provides for extensive analysis of conflicts between the strength of incentives and the strength of commitment. ${ }^{26}$ Under lack of commitment productivity gains from incentives would be punished by tighter incentives, which leave the firm with less profits. Knowing or expecting this, firms would refrain from productivity improvements. In principle, the same holds for investments that lead to cost reductions or are sunk. Thus, commitment appears to be valuable. ${ }^{27}$

However, there is a widespread inability to commit. Regulators face legal constraints on commitment. Changes in regulatory personnel hinder personal commitments by previous regulators. There is an impossibility to write complete regulatory contracts.

At the same time it can often be sub-optimal to exercise commitment. Flexibility may be highly valuable in a changing environment. This not only holds for learning from mistakes but also for the inability under commitment to adapt to new situations.

A lack of commitment can be exogenous, reflecting a change in outside variables, such as inflation or political elections. It can also be endogenous, reflecting a change in regulatory variables, such as profit or investments (Grajek and Röller, 2009). Potential drivers for the effects of lack of commitment are efficiency, fairness and political influence.

Commitment can be good for investment to the extent that it provides a reliable basis for the investment decisions and overcomes dynamic inconsistency of the regulators. It also prevents any ex post regulatory bias against profits. This is particularly relevant for infrastructure innovations with their potential for high profits or high losses. As an

\footnotetext{
${ }^{26}$ For other relevant work see Baron and Besanko (1987), Gilbert and Newbery (1994) and Levy and Spiller (1996).

${ }^{27}$ Commitment appears to be particularly valuable, when it comes to investments. Innovations not based on investments but rather on learning by doing may be achievable without commitment. See Lewis and Yildirim (2002).
} 
example symmetric profit and loss sharing can overcome the regulatory truncation problem. However, loss sharing cannot fully insure the firm (because consumers can opt out). Commitment is also relevant for cost-reducing incentives that potentially increase profits.

The effects of a lack of commitment depend on the political/legal environment ("institutional endowment"). In a culture of symmetric fairness regulated firms may be shielded against large losses even if there is no commitment. In particular, the lack of commitment can deal with unexpected technological/market changes and can correct mistakes.

As a result, commitment needs balancing with sensible flexibility/incentives (Levy and Spiller, 1996). The ability to achieve that is the strength of due process (U.S. approach). Due process rules themselves can be quite stable, depending on a country's legal traditions. At the same time, they allow for flexibility but generally make it hard to implement sudden policy changes.

In general, the longer the time horizon of a regulatory decision the less regulators can commit. Infrastructure investments have long lead times and long lives. As a result full regulatory commitment for the time horizon of an investment is not possible. A general result of the literature on Bayesian incentive regulation is that the less the regulator can commit to incentives (and the associated profits and losses) the weaker should incentives be. The compatibility of incentive regulation and efficient investment is therefore in doubt

Based on this insight I propose a two-period framework (based on Vogelsang, 2006), distinguishing a short period and a long period.

The short period typically coincides with the length of a regulatory lag, or of (RPI$\mathrm{X}$ )-type adjustments or adjustments from profit sharing. During a short period the firm makes and executes decisions on operations, repairs and maintenance costs. For the time of a short period full regulatory commitment and steep incentives for cost reductions are feasible.

The long (commitment) period corresponds to the time for revisions of (RPI-X)adjustments and of incentive mechanisms at the end of each long period. It could also correspond to the length of long-term contracts. Almost full commitment to incentives is 
feasible inside a long period. However, beyond the long period such commitment is generally not feasible.

Infrastructure investments go beyond several long periods so that only very basic regulatory commitment is possible for the time horizon of such investments. Consequently, little or no cost-reducing regulatory incentives are feasible over the time period relevant for infrastructure investment.

How is the above discussion of the tightness of regulation affected by the two-period framework? First, too soft regulation is likely to lead to excess profits over time. Since such profits tend to be unacceptable to the public and hence to regulators, they reduce the length of the commitment period. Second, conversely, too tight regulation is likely to lead to losses over time. Since losses are also unacceptable to regulators, they also reduce the length of the commitment period. In contrast to both, intermediate regulation is less likely to lead to either excessive profits or excessive losses and is therefore more likely to be viable for longer than either soft or tight regulation. As a consequence, intermediate regulation enhances the commitment power and investment incentives. Intermediate regulation is compatible with short-term incentive regulation and extends the length of the short period. However, how can regulators commit to "intermediate regulation" in the first place?

In the following we consider several approaches to intermediate regulation with some commitment power.

\subsection{A variant of rate-of-return regulation}

In the U.S. rate-of-return regulation has provided strong commitment for many decades and was generally associated with an allowed rate of return $\geq$ cost of capital (Evans and Garber, 1988). ${ }^{28}$ In practice, rate-of-return regulation (intermediate to soft regulation) has been combined with a used-and-useful criterion for including assets in the rate base. This may counter any Averch-Johnson type overcapitalization tendencies. In fact, according to Gilbert and Newbery (1994) and Newbery (2000) it provides for an efficient approach to investing. At the same time, in the U.S., rate-of-return regulation represents a credible commitment because of Supreme Court decisions ("Hope"). And the

\footnotetext{
${ }^{28}$ See, however, Joskow and MacAvoy (1975), for a period, where electricity rates were not cost covering.
} 
used-and-useful criterion has been subject to extensive court review there. It may, however, introduce new regulatory uncertainties that could reduce investment incentives/ increase the cost of capital (Baumol and Sidak, 2002; Égert, 2009) ${ }^{29}$ State-of-the-art cost models may reduce this uncertainty but will increase the costs and (initially) the time lag due to regulation.

How can the rate-of-return regulation with used-and-useful criterion be combined with incentive regulation for cost reduction (and efficient pricing)? Price-cap regulation has been described as rate-of-return regulation with a pre-specified, long regulatory lag (Liston, 1993). Using this insight, rate-of-return regulation only needs to be applied at RPI-X updates. ${ }^{30}$ This provides for some incentives and flexibility. Investment risks can further be reduced through the use of historic cost standards (Égert, 2009). Further downward flexibility through price caps could reduce any inefficiencies stemming from out-of-date historic costs.

While at first blush this suggestion appears to be tailor-made for the U.S. only, it has to be kept in mind that current updates of price-cap regulation outside the U.S. also rely very heavily on rate-of-return criteria (in the form of actual and permissible WACC).

\subsection{Regulatory holidays}

A second option for implementing intermediate regulation with some commitment consists of regulatory holidays, which can be viewed as a form of commitment. Gans and King (2002 and 2003) establish conditions under which access holidays can increase investment incentives for innovative infrastructure.

Regulatory holidays mean that regulation only begins with a lag after conditions for regulation (the regulatory requirement) have been met. ${ }^{31}$ This lag can be viewed as a short period, for which commitment is feasible. In that case, the holiday is unlikely to be long enough for financing large sunk investments. Baake et al. (2005) therefore describe a scheme for establishing a longer regulatory holiday. At the same time, a commitment to such a long holiday for, say, 10-15 years may not really be credible. However, breaking

\footnotetext{
${ }^{29}$ Égert (2009) also points out that the regulated firm may choose projects that will have a lower variance of expected outcomes if the investments will be judged with ex post information.

${ }^{30}$ Similarly, it can be applied to other incentive-regulation updates, such as new profit-sharing formulas or benchmark updates.

${ }^{31}$ When I talked in Peru about regulatory holidays the chief regulator of Osiptel, Guillermo Thornberry, asked: What is that? I have not had a holiday in $2 \frac{1}{2}$ years!
} 
this kind of commitment and installing regulation may itself take time so that the "long period" in this case is likely to be longer than ordinary long periods.

Unless they provide an incumbent with an insurmountable lead, regulatory holidays could be combined with intermediate regulation (based on the rate-of-return regulation variety discussed in the previous section) after the holidays expire. A combination of intermediate regulation with regulatory holidays could then spur investment.

A major problem of regulatory holidays is that verifiable standards are needed to determine under which conditions regulatory holidays would be warranted. An example could be the very narrow definition of innovation under the EU approach, i.e., the nonapplicability of the EU communications framework three-criteria test mentioned above in Section 4. A somewhat wider criterion would be the creation of a new market, independent of the applicability of the three-criteria test. However, defining a new market poses itself severe difficulties, because the hypothetical monopoly test is usually hard to adapt to this case (Gual, 2003).

Related to regulatory holidays is full and therefore (initially) unlimited deregulation of innovations and particularly risky infrastructure investments. The problem in both cases is that of finding criteria for such deregulation, which would have to be at least as strict as those for a regulatory holiday. ${ }^{32}$ Deregulation does not necessarily include a credible commitment against re-regulation. However, a long lag is likely before reregulation becomes feasible. The FCC has some discretion of regulatory forbearance under the U.S. Telecommunications Act of 1996. It can refrain from regulation that reduces investment incentives. An example has been the lifting of unbundling requirements for the UNE-P (Platform of unbundled network elements) in 2004. In contrast to regulatory forbearance the FCC can actually exercise deregulation as a more credible commitment. This option has been exercised by the FCC for new fiber lines and it is claimed by proponents to have increased fiber deployment.

Some countries have sunset clauses, under which regulation would end after a prespecified period of time. However, for example in Canada, they have raised commitment issues through extension of the sunset period (citation!).

\footnotetext{
${ }^{32}$ Of course, the usual criteria for deregulation, which were established for legacy markets, would continue to hold for innovative markets. This would include the non-fulfillment of the three-criteria test to the extent that it can be measured.
} 


\subsection{Infrastructure sharing and long-term contracts}

Two approaches for facilitating bottleneck infrastructure investments are infrastructure sharing and long-term contracts (for access or unbundled network elements) between incumbent and alternative competitors. In both cases the investment risk is shared between incumbent and alternative competitors. The basic question in these cases is, to what extent does the type of regulation of infrastructure access change the overall risk of innovative infrastructure investments (rather than only its distribution)? Is some version of the Modigliani-Miller theorem applicable here?

Infrastructure sharing between incumbent and access seekers can take the form of joint ownership so that infrastructure sharing commitments can cover the investment period. In this case there is genuine risk sharing ex ante. On top of that there are going to be real effects, because the infrastructure sharing reduces ex ante (first-mover) competition and affects competition ex post (which can be softer or fiercer, see Ilic et al., 2009). Infrastructure sharing involves complex, long-term transactions with monitoring and collusion problems.

Long-term contracts (ex ante) between incumbent and access seekers move away from the customary mandated short-term access, which provides a risk-free option for access seekers (Hausman, 1997; Pindyck, 2004). In contrast, long-term contracts would be desirable and there should be a surcharge for short-term access that would equal the value of the option. From a commitment perspective and because they tend to be incomplete, long-term supply contracts probably cannot cover the entire investment period.

\subsection{Repair models for insufficient investments under regulation}

There exist a number of repair models for insufficient investments under regulation. They have in common that they only cover specific types of investment or that they apply only to specific industries. ${ }^{33}$

Widespread universal service subsidies in telecommunications, now under discussion for broadband access, typically have one part of an industry or one class of consumers subsidize another. Most such mechanisms introduce some allocative inefficiency in the

\footnotetext{
${ }^{33}$ Kwoka (2009) discusses several approaches in this area.
} 
course of financing, for example, rural infrastructure. Public subsidies are the source of 2009 stimulus packages for broadband access in several countries. ${ }^{34}$

Regulators have extorted investment commitment by regulated telecommunications carriers in exchange for favorable regulation, e.g., in New York state around 1990.

Generation resource adequacy regulation has been introduced in a number of U.S. states in order to compensate investment disincentives from regulated electricity generation spot pricing. ${ }^{35}$

It appears that repair models for lack of investment can be most appropriate if the output produced with such investments has strong public goods properties and therefore cannot efficiently be sold in markets (like, for example, electricity reliability). They may also be called for if quality of service is being jeopardized by incentive regulation. As Kwoka (2009) points out, quality may involve costs that were not contemplated in incentive regulation.

\section{Conclusions}

I take a fairly general rather than case-specific approach to the relationship between regulation and investment. Nevertheless, the regulator will have to determine if investment problems and/or innovations play a major role in the particular industry. If that is the case then there are two main regulatory concerns for investment/innovation. They are uncertainty and the lack of regulatory commitment over the long time horizon associated with investment.

Uncertainty leads to the truncation issue and thereby to an asymmetric error distribution that favors intermediate over tight and soft regulation. The regulatory commitment problem also favors intermediate regulation. In addition, it favors a regulatory review cycle with true-ups based on actual costs and based on rate-of-return criteria.

The best balance between commitment and flexibility/incentives depends on a country's institutional endowment, for example on its due process rules (Levy and Spiller, 1996).

\footnotetext{
${ }^{34}$ For the contrasting effects of fiscal versus regulatory measures see Bauer (2009).

${ }^{35}$ For an extensive critique and literature review of generation adequacy, see Roques (2008).
} 
Genuine innovations should not be regulated. However, strict and verifiable standards are needed for deregulation and for regulatory holidays based on the "innovation" argument. Under weaker criteria innovative infrastructure should be regulated lightly. An example for weak criteria for the presence of innovations could be the first applicability of EU communications framework three-criteria test. ${ }^{36}$

\section{References}

Ai, Chunrong and David E.M. Sappington (2002), "The impact of state incentive regulation on the US telecommunications industry", Journal of Regulatory Economics 22, pp. 133-160.

Armstrong, Mark, Cowan, Simon, and John Vickers (1994), Regulatory Reform Economic Analysis and British Experience, Cambridge, Mass., and London: MIT Press.

Armstrong, Mark and David E.M. Sappington (2006), "Regulation, competition and liberalization", Journal of Economic Literature 44, pp. 325-366.

Armstrong, Mark and David E.M. Sappington (2007), "Recent Developments in the Theory of Regulation," in M. Armstrong and R. Porter (eds.), Handbook of Industrial Organization, Vol. III, Amsterdam: North Holland.

Avenali, Alessandro, Giorgio Matteucci and Pierfrancesco Reverberi (2010), "Dynamic access pricing and incentives to invest in alternative infrastructures", International Journal of Industrial Organization 28, pp. 167-175.

Baake, Pio, Ulrich Kamecke and Christian Wey (2005), “A regulatory framework for new and emerging markets: Dynamic solutions to policy failures", Communications \& Strategies No. 60, pp. 123-136.

Bailey, Elizabeth E. and Roger D. Coleman (1971), "The effect of lagged regulation in an Averch-Johnson model”, Bell Journal of Economics and Management Science 2, pp. 278-292.

Banerjee, Aniruddha (2003), "Does incentive regulation 'cause' degradation of retail telephone service quality?", Information Economics and Policy 15, pp. 243-269.

\footnotetext{
${ }^{36}$ The threat of (light-handed) regulation may not be credible, though (Haucap et al., 2007). Examples for light regulation from Germany include a combination of an ex-post approach with applying competition policy standards.
} 
Baron, David P. and David Besanko (1987), "Commitment and Fairness in a Dynamic Regulatory Relationship”, Review of Economic Studies 54, pp. 413-436.

Baron, David P. and Roger B. Myerson (1982), "Regulating a Monopolist with Unknown Costs”, Econometrica 50, pp. 911-930.

Bauer, Johannes M. (2009), "Regulation, Public Policy, and Investment in Communications Infrastructure", SSRN Working Paper, April 2, available at: http://papers.ssrn.com/sol3/papers.cfm?abstract_id=1339043.

Baumol, William J. (1968), "Reasonable Rules for Rate Regulation: Plausible Polices for an Imperfect World," in A. Phillips and O. E. Williamson (eds.), Prices: Issues in Theory, Practice, and Public Policy, Philadelphia: University of Pennsylvania Press, pp. 101-123.

Baumol, William J. (1982), "Productivity Adjustment Clauses and Rate Adjustment for Inflation," Public Utilities Fortnightly, July 22, pp. 11-18.

Baumol, William J. and Alvin K. Klevorick (1970), "Input choices and rate-of-return regulation: An overview of the discussion", Bell Journal of Economics and Management Science 1, pp. 162-190.

Baumol, William J. and J. Gregory Sidak (2002), "The Pig in the Python: Is Lumpy Capacity Investment Used and Useful?", Energy Law Journal 23, pp. 383-458.

Bawa, Vijay S. and David S. Sibley (1980), "Dynamic Behavior of a Firm Subject to Stochastic Regulatory Review", International Economic Review 21, pp. 627-642.

Borrmann, Jörg and Gert Brunekreeft (2009), “The Effect of Monopoly Regulation on the Timing of Investment," mimeo, Jacobs University Bremen and University of Vienna, September 16.

Bourreau, Marc and Pinar Doğan (2004), "Service-based versus facilites-based competition in local access networks", Information Economics and Policy 16, pp. 287-306.

Bourreau, Marc and Pinar Doğan (2005), "Unbundling the Local Loop", European Economic Review 49, pp. 173-199.

Bourreau, Marc and Pinar Doğan (2006), “'Build-or-Buy Strategies in the Local Loop”, American Economic Review 96(2), pp. 72-76. 
Brito, Duarte, Pedro Pereira, and João Vareda (2008), “Can Two-Part Tariffs Promote Efficient Investment on Next Generation Networks?," mimeo, October.

Cabral, Luis and Michael Riordan (1989), “Incentives for Cost Reduction Under Price Cap Regulation," Journal of Regulatory Economics 1, pp. 93-102.

Cambini, Carlo, and Yanyan Jiang (2009), "Broadband investment and regulation: A literature review", Telecommunications Policy 33, pp. 559-574.

Cave, Martin (2006), "Ecouraging infrastructure investment via the ladder of investment", Telecommunications Policy 30, pp. 223-237.

Cave, Martin and Ingo Vogelsang (2003), "How Access Pricing and Entry Interact", Telecommunications Policy 27, pp. 717-727.

Comacho, Fernando T. and Flavio M. Menezes (2009), “ Access pricing and investment: A real options approach", Journal of Regulatory Economics 36(2), pp. 107-126.

Égert, Balázs (2009), "Infrastructure Investment in Network Industries: The Role of Incentive Regulation and Regulatory Independence", OECD Economics Department Working Paper No. 688.

Evans, Lewis T. and Steven Garber (1988), "Public Utility Regulators Are Only Human: A Positive Theory of Regulatory Constraints," American Economic Review 78, pp. 444-462.

Evans, Lewis T. and Graeme A. Guthrie (2005), "Risk, price regulation, and irreversible investment," International Journal of Industrial Organization 23, pp. 109-128.

Evans, Lewis T. and Graeme A. Guthrie (2006), "Incentive regulation of prices when costs are sunk", Journal of Regulatory Economics 29, pp. 239-264.

Evans, Joanne, Paul Levine and Francensc Trillas (2008), "Lobbies, delegation and the under-investment problem in regulation", International Journal of Industrial Organization 26, pp. 17-40.

Faulhaber, Gerald R. (2003), "Policy-induced competition: the telecommunications experiments", Information Economics and Policy 15, pp. 73-97.

Gans, Joshua (2001), "Regulating private infrastructure investments: Optimal pricing for access to essential facilities", Journal of Regulatory Economics 20, pp. 167-189. 
Gans, Joshua and Stephen King (2002), “Access Holidays and the Timing of Infrastructure Investment”, Melbourne Business School Working Paper No. 2002-14, available at: http://ssrn.com/sol3/papers.cfm?abstract id=361500.

Gans, Joshua and Stephen King (2003), “Access Holidays for Network Infrastructure Investment", Agenda 10, pp. 163-178.

Gilbert, Richard and David M. Newbery (1994), "The Dynamic Efficiency of Regulatory Constitutions," RAND Journal of Economics 25, pp. 538-554.

Grajek, Michal and Lars-Hendrik Röller (2009), “The Effect of Regulation on Investment in Network Industries: Evidence from European Telecoms", ESMT Working Paper No. 09-004, June 15, available at: http://papers.ssrn.com/sol3/papers.cfm?abstract_id=1448666.

Greenstein, Shane, Susan McMaster and Pablo Spiller (1995), "The effect of incentive regulation on infrastructure modernization: Local exchange companies' deployment of digital technology", Journal of Economics \& Management Strategy 4, pp. 187-236. Gual, Jordi (2003), "Market Definition in the Telecoms Industry", Centre for Economic Policy Research, Discussion Paper Series No. 3988, available at: http://www.iese.edu/research/pdfs/DI-0517-E.pdf.

Guthrie, Graeme (2006), "Regulating Infrastructure: The Impact on Risk and Investment“, Journal of Economic Literature 44, pp. 925-972.

Haucap, Justus, Ulrich Heimeshoff, and André Uhde (2007), "Credible Threats as an Instrument of Regulation for Network Industries", in Paul J.J. Welfens and Mathias Weske (eds.), Digital Economic Dynamics Innovations, Networks and Regulations, Berlin: Springer Verlag, pp. 171-202.

Hazlett Thomas W. and Coleman Bazelon (2005), "Regulated Unbundling of Telecommunications Networks: A Stepping Stone to Facilities-Based Competition?", Paper presented at the Telecommunications Policy Research Conference, Septmeber 23-25, available at: http://mason.gmu.edu/ thazlett/pubs/Stepping\%20Stone\%20TPRC.10.04.05\%20.pdf. Hausman, Jerry A. (1997), "Valuing the Effect of Regulation on New Services in Telecommunications", Brookings Papers on Economic Activity, Microeconomics, S. $1-38$. 
Holznagel, Bernd and Ingo Vogelsang (2009), "Weiterentwicklung der TK-Regulierung im Lichte neuer Herausforderungen und ökonomischer Erkenntnisse" in Haucap, J. \& J. Kuehling (eds.), Effiziente Rahmenbedingungen für Telekommunikationsmärkte in der Zukunft: Kartellrecht, Netzneutralität und Preis-Kosten-Scheren, Baden-Baden: Nomos Verlag, pp. 13-114.

Hori, Keiichi and Keizo Mizuno (2006), “Access pricing and investment with stochastically growing demand”, International Journal of Industrial Organization 24, pp. $795-808$

Hori, Keiichi and Keizo Mizuno (2009), "Competition schemes and investment in network infrastructure under uncertainty," Journal of Regulatory Economics 35, pp. 179-200.

Ilic, Dragan, Karl-Heinz Neumann and Thomas Plückebaum (2009), "The Economics of Next Generation Access - Addendum”, WIK-Consult GmbH, Bad Honnef, Germany, July 15, available at: http://www.wik.org/content/ecta_study_addendum_2009.pdf.

Joskow, Paul L. and Paul W. MacAvoy (1975), "Regulation and the Financial Conditions of the Electric Power Companies in the 1970s," American Economic Review 65, pp. 295-311.

Kotakorpi, Kaisa (2006), “Access price regulation, investment and entry in telecommunications", International Journal of Industrial Organization 24, pp. 10131020 .

Kwoka, John (2009), "Investment Adequacy under Incentive Regulation”, mimeo, Northeastern University.

Laffont, Jean-Jacques and Jean Tirole (1986), "Using Cost Observation to Regulate Firms", Journal of Policitical Economy 94, pp. 614-641.

Laffont, Jean-Jacques and Jean Tirole (1993), A Theory of Incentives in Procurement and Regulation. Cambridge, MA: The MIT Press .

Laffont, Jean-Jacques and Jean Tirole (2000), Competition in Telecommunications. Cambridge, MA: The MIT Press.

Levy, Brian and Pablo T. Spiller (eds.) (1996), Regulation, Institutions, and Commitment, Cambridge, UK, New York and Melbourne: Cambridge University Press. 
Lewis, Tracy R. and Huseyin Yildirim (2002), "Learning by doing and dynamic regulation", RAND Journal of Economics 33, pp. 22-36.

Liston, Catherine (1993), "Price-Cap versus Rate-of-Return Regulation," Journal of Regulatory Economics 5, pp. 25-48.

Littlechild, Stephen C. (1983), Regulation of British Telecommunications' Profitability, Report to the Secretary of State, Department of Industry, London: Her Majesty's Stationery Office.

Mandy, David M. (2009), "Pricing inputs to induce efficient Make-or-Buy decisions," Journal of Regulatory Economics 36, pp. 29-43.

Manne, Geoffrey A. and Joshua D. Wright (2009), "The Limits of Antitrust in the New Economy", available at: http://papers.ssrn.com/sol3/papers.cfm?abstract_id=1490849.

Moretto, Michel, Paolo M. Panteghini and Carlo Scarpa (2008), "Profit sharing and investment by regulated utilities: A welfare analysis", Review of Financial Economics 17 , pp. 315-337.

Nagel, Thomas and Margarethe Rammerstorfer (2008), "Price regulation and Investment Behavior - How Real Options can Explain Underinvestment", Vienna University of Economics and Business Administration, available at: http://ssrn.com/abstract=1009123.

Newbery, David M. (2000), Privatization, Restructuring, and Regulation of Network Industries, Cambridge, MA, and London: MIT Press.

Panteghini, Paolo M. and Carlo Scarpa (2003), "Irreverisble investment and regulatory risk", CESifo Working Paper No. 934, April, available at http://ssrn.com/abstract=404581.

Pindyck, Robert S. (2004), "Mandatory Unbundling and Irreversible Investment in Telecom Networks", NBER Working Paper No. 10287.

Roques, Fabian A. (2008), "Market Design for Generation Adequacy: Healing Causes rather than Symptoms", ERPG Working Paper 0810 \& CWPE Working Paper 0821, May, available at: http://www.eprg.group.cam.ac.uk/wpcontent/uploads/2008/11/nts0810.pdf.

Roques, Fabien A. and Nicos S. Savva (2006), "Price Cap Regulation and Investment Incentives Under Demand Uncertainty", CWPE 0636 and EPRG 0616, May, 
available

at:

http://www.eprg.group.cam.ac.uk/wp-

content/uploads/2008/11/eprg0616.pdf.

Roques, Fabien A. and Nicos S. Savva (2009), "Investment under uncertainty with price ceilings in oligopolies", Journal of Economic Dynamics and Control 33(2), pp. 507524.

Sappington, David E.M. (2005a), "Regulating Service Quality: A Survey," Journal of Regulatory Economics 27, pp. 123-154.

Sappington, David E.M. (2005b), "On the Irrelevance of Input Prices for Make-or-Buy Decisions", American Economic Review 95, pp. 1631-1638.

Shavell, Steven (1984), "Liability for Harm Versus Regulation of Safety", Journal of Legal Studies 13, pp. 357-374.

Sobel, Joel (1999), “A Reexamination of Yardstick Competition”, Journal of Economics \& Management Strategy 8, pp. 33-60.

Vareda, João and Steffen Hoernig (2007), "The race for telecoms infrastructure investment with bypass: Can access regulation achieve the first best?", CEPR Discussion Paper No. DP6203.

Vogelsang, Ingo (2001), "Price Regulation for Independent Transmission Companies," Journal of Regulatory Economics 20, pp. 141-165.

Vogelsang, Ingo (2002), "Incentive Regulation and Competition in Public Utility Markets: A 20-Year Perspective,” Journal of Regulatory Economics 22, pp. 5-28.

Vogelsang, Ingo (2006), "Electricity Transmission Pricing and Performance-Based Regulation," The Energy Journal 27, pp. 97-126.

Vogelsang, Ingo, and J. Finsinger (1979), "A Regulatory Adjustment Process for Optimal Pricing by Multiproduct Monopoly Firms," Bell Journal of Economics 10, pp. 157171.

Weisman, Dennis (2005), "Price regulation and quality", Information Economics and Policy 17, pp. 165-174. 


\section{CESifo Working Paper Series}

for full list see www.cesifo-group.org/wp

(address: Poschingerstr. 5, 81679 Munich, Germany, office@cesifo.de)

2901 Donatella Gatti, Christophe Rault and Anne-Gaël Vaubourg, Unemployment and Finance: How do Financial and Labour Market Factors Interact?, December 2009

2902 Arno Riedl, Behavioral and Experimental Economics Can Inform Public Policy: Some Thoughts, December 2009

2903 Wilhelm K. Kohler and Marcel Smolka, Global Sourcing Decisions and Firm Productivity: Evidence from Spain, December 2009

2904 Marcel Gérard and Fernando M. M. Ruiz, Corporate Taxation and the Impact of Governance, Political and Economic Factors, December 2009

2905 Mikael Priks, The Effect of Surveillance Cameras on Crime: Evidence from the Stockholm Subway, December 2009

2906 Xavier Vives, Asset Auctions, Information, and Liquidity, January 2010

2907 Edwin van der Werf, Unilateral Climate Policy, Asymmetric Backstop Adoption, and Carbon Leakage in a Two-Region Hotelling Model, January 2010

2908 Margarita Katsimi and Vassilis Sarantides, Do Elections Affect the Composition of Fiscal Policy?, January 2010

2909 Rolf Golombek, Mads Greaker and Michael Hoel, Climate Policy without Commitment, January 2010

2910 Sascha O. Becker and Ludger Woessmann, The Effect of Protestantism on Education before the Industrialization: Evidence from 1816 Prussia, January 2010

2911 Michael Berlemann, Marco Oestmann and Marcel Thum, Demographic Change and Bank Profitability. Empirical Evidence from German Savings Banks, January 2010

2912 Øystein Foros, Hans Jarle Kind and Greg Shaffer, Mergers and Partial Ownership, January 2010

2913 Sean Holly, M. Hashem Pesaran and Takashi Yamagata, Spatial and Temporal Diffusion of House Prices in the UK, January 2010

2914 Christian Keuschnigg and Evelyn Ribi, Profit Taxation and Finance Constraints, January 2010

2915 Hendrik Vrijburg and Ruud A. de Mooij, Enhanced Cooperation in an Asymmetric Model of Tax Competition, January 2010 
2916 Volker Meier and Martin Werding, Ageing and the Welfare State: Securing Sustainability, January 2010

2917 Thushyanthan Baskaran and Zohal Hessami, Globalization, Redistribution, and the Composition of Public Education Expenditures, January 2010

2918 Angel de la Fuente, Testing, not Modelling, the Impact of Cohesion Support: A Theoretical Framework and some Preliminary Results for the Spanish Regions, January 2010

2919 Bruno S. Frey and Paolo Pamini, World Heritage: Where Are We? An Empirical Analysis, January 2010

2920 Susanne Ek and Bertil Holmlund, Family Job Search, Wage Bargaining, and Optimal Unemployment Insurance, January 2010

2921 Mariagiovanna Baccara, Allan Collard-Wexler, Leonardo Felli and Leeat Yariv, Gender and Racial Biases: Evidence from Child Adoption, January 2010

2922 Kurt R. Brekke, Roberto Cellini, Luigi Siciliani and Odd Rune Straume, Competition and Quality in Regulated Markets with Sluggish Demand, January 2010

2923 Stefan Bauernschuster, Oliver Falck and Niels Große, Can Competition Spoil Reciprocity? - A Laboratory Experiment, January 2010

2924 Jerome L. Stein, A Critique of the Literature on the US Financial Debt Crisis, January 2010

2925 Erkki Koskela and Jan König, Profit Sharing, Wage Formation and Flexible Outsourcing under Labor Market Imperfection, January 2010

2926 Gabriella Legrenzi and Costas Milas, Spend-and-Tax Adjustments and the Sustainability of the Government's Intertemporal Budget Constraint, January 2010

2927 Piero Gottardi, Jean Marc Tallon and Paolo Ghirardato, Flexible Contracts, January 2010

2928 Gebhard Kirchgässner and Jürgen Wolters, The Role of Monetary Aggregates in the Policy Analysis of the Swiss National Bank, January 2010

2929 J. Trent Alexander, Michael Davern and Betsey Stevenson, Inaccurate Age and Sex Data in the Census PUMS Files: Evidence and Implications, January 2010

2930 Stefan Krasa and Mattias K. Polborn, Competition between Specialized Candidates, January 2010

2931 Yin-Wong Cheung and Xingwang Qian, Capital Flight: China’s Experience, January 2010 
2932 Thomas Hemmelgarn and Gaetan Nicodeme, The 2008 Financial Crisis and Taxation Policy, January 2010

2933 Marco Faravelli, Oliver Kirchkamp and Helmut Rainer, Social Welfare versus Inequality Concerns in an Incomplete Contract Experiment, January 2010

2934 Mohamed El Hedi Arouri and Christophe Rault, Oil Prices and Stock Markets: What Drives what in the Gulf Corporation Council Countries?, January 2010

2935 Wolfgang Lechthaler, Christian Merkl and Dennis J. Snower, Monetary Persistence and the Labor Market: A New Perspective, January 2010

2936 Klaus Abberger and Wolfgang Nierhaus, Markov-Switching and the Ifo Business Climate: The Ifo Business Cycle Traffic Lights, January 2010

2937 Mark Armstrong and Steffen Huck, Behavioral Economics as Applied to Firms: A Primer, February 2010

2938 Guglielmo Maria Caporale and Alessandro Girardi, Price Formation on the EuroMTS Platform, February 2010

2939 Hans Gersbach, Democratic Provision of Divisible Public Goods, February 2010

2940 Adam Isen and Betsey Stevenson, Women's Education and Family Behavior: Trends in Marriage, Divorce and Fertility, February 2010

2941 Peter Debaere, Holger Görg and Horst Raff, Greasing the Wheels of International Commerce: How Services Facilitate Firms’ International Sourcing, February 2010

2942 Emanuele Forlani, Competition in the Service Sector and the Performances of Manufacturing Firms: Does Liberalization Matter?, February 2010

2943 James M. Malcomson, Do Managers with Limited Liability Take More Risky Decisions? An Information Acquisition Model, February 2010

2944 Florian Englmaier and Steve Leider, Gift Exchange in the Lab - It is not (only) how much you give ..., February 2010

2945 Andrea Bassanini and Giorgio Brunello, Barriers to Entry, Deregulation and Workplace Training: A Theoretical Model with Evidence from Europe, February 2010

2946 Jan-Emmanuel De Neve, James H. Fowler and Bruno S. Frey, Genes, Economics, and Happiness, February 2010

2947 Camille Cornand and Frank Heinemann, Measuring Agents’ Reaction to Private and Public Information in Games with Strategic Complementarities, February 2010

2948 Roel Beetsma and Massimo Giuliodori, Discretionary Fiscal Policy: Review and Estimates for the EU, February 2010 
2949 Agnieszka Markiewicz, Monetary Policy, Model Uncertainty and Exchange Rate Volatility, February 2010

2950 Hans Dewachter and Leonardo Iania, An Extended Macro-Finance Model with Financial Factors, February 2010

2951 Helmuth Cremer, Philippe De Donder and Pierre Pestieau, Education and Social Mobility, February 2010

2952 Zuzana Brixiová and Balázs Égert, Modeling Institutions, Start-Ups and Productivity during Transition, February 2010

2953 Roland Strausz, The Political Economy of Regulatory Risk, February 2010

2954 Sanjay Jain, Sumon Majumdar and Sharun W. Mukand, Workers without Borders? Culture, Migration and the Political Limits to Globalization, February 2010

2955 Andreas Irmen, Steady-State Growth and the Elasticity of Substitution, February 2010

2956 Bengt-Arne Wickström, The Optimal Babel - An Economic Framework for the Analysis of Dynamic Language Rights, February 2010

2957 Stefan Bauernschuster and Helmut Rainer, From Politics to the Family: How Sex-Role Attitudes Keep on Diverging in Reunified Germany, February 2010

2958 Patricia Funk and Christina Gathmann, How do Electoral Systems Affect Fiscal Policy? Evidence from State and Local Governments, 1890 to 2005, February 2010

2959 Betsey Stevenson, Beyond the Classroom: Using Title IX to Measure the Return to High School Sports, February 2010

2960 R. Quentin Grafton, Tom Kompas and Ngo Van Long, Biofuels Subsidies and the Green Paradox, February 2010

2961 Oliver Falck, Stephan Heblich, Alfred Lameli and Jens Suedekum, Dialects, Cultural Identity, and Economic Exchange, February 2010

2962 Bård Harstad, The Dynamics of Climate Agreements, February 2010

2963 Frederick van der Ploeg and Cees Withagen, Is There Really a Green Paradox?, February 2010

2964 Ingo Vogelsang, Incentive Regulation, Investments and Technological Change, February 2010 